\title{
Ethnic Discrimination in Multi-ethnic Societies: Evidence from Russia
}

\author{
Alexey Bessudnov $\mathbb{D}^{1, *}$ and Andrey Shcherbak $\mathbb{D}^{2}$ \\ ${ }^{1}$ University of Exeter, Clayden Building, Streatham Rise, Exeter EX4 4PE, UK and ${ }^{2}$ National Research \\ University Higher School of Economics, 20 Myasnitskaya ul., Moscow 101000, Russia \\ ${ }^{*}$ Corresponding author. Email: a.bessudnov@exeter.ac.uk
}

Submitted February 2019; revised July 2019; accepted August 2019

\begin{abstract}
Field experiments have provided ample evidence of ethnic and racial discrimination in the labour market. Less is known about how discrimination varies in multi-ethnic societies, where the ethnic composition of populations is different across locations. Inter-group contact and institutional arrangements for ethnic minorities can mitigate the sense of group threat and reduce discrimination. To provide empirical evidence of this, we conduct a field experiment of ethnic discrimination in Russia with a sample of over 9,000 job applications. We compare ethnically homogeneous cities and cities with ethnically mixed populations and privileged institutional status of ethnic minorities. We find strong discrimination against visible minorities in the former but much weaker discrimination in the latter. These findings demonstrate how institutions and historical contexts of inter-group relations can affect ethnic prejudice and discrimination.
\end{abstract}

\section{Introduction}

The field experiment has now become a standard method for studying racial and ethnic discrimination in the labour market. In a typical labour market experiment (also known as an audit or correspondence study), researchers randomly assign a signal of race or ethnicity to fictitious CVs, apply for jobs and record contacts from employers. As long as the signal assignment is random, the differences in the contact rates across the groups can be treated as evidence of discrimination. Such experiments have now been conducted in many countries [for recent literature reviews, see Rich (2014); Zschirnt and Ruedin (2016); Bertrand and Duflo (2017); Baert (2018); and Neumark (2018)]. There is overwhelming evidence that on average employers contact applicants from majority groups more often than applicants from minority groups. Racial and ethnic discrimination in the labour market is well documented.

In this article, we present the results of the first ethnic discrimination experiment conducted in Russia. We focus on two main questions.

First, attitudes of ethnic majorities towards different minority groups are not the same, and vary according to an implicit hierarchy. In Western countries, minority groups of European origin are usually more widely accepted than groups of African and Asian origin (Hagendoorn, 1995). Most field experiments to date looked at one or only a few minority groups. Even the larger audit studies rarely had enough statistical power to provide reliable estimates of the differences in contact rates across minority groups. In this study, we implement a design with 10 ethnic groups and a sample size 
of over 9,000 job applications that allows us to provide reliable estimates of discrimination for each group and explore the ethnic hierarchy for multiple groups in Russia.

Second, we focus on geographical variation in discrimination. Russia is a multi-ethnic federation where, in some regions, indigenous ethnic groups have a special institutional status. Are the patterns of ethnic discrimination and hierarchy the same or different in ethnically heterogeneous, compared with ethnically Russian, regions? To answer this question, we conducted our experiment in four Russian cities. Two of them (Moscow and St. Petersburg) are metropolitan areas, with mostly ethnically Russian populations. The other two cities (Kazan and Ufa) are capitals of ethnic autonomies, with mixed ethnic Russian and indigenous Muslim populations.

The results show considerable differences in the patterns of ethnic discrimination across these locations. In Moscow and St. Petersburg, employers discriminate against visible ethnic minorities of Southern origin but not against groups of European origin. Discrimination against ethnic minority men is stronger than that against ethnic minority women. On the other hand, in Kazan and Ufa, all ethnic groups are treated by employers in approximately the same way, with the contact rates for most groups of Southern origin being only marginally, and not statistically significantly, lower than for groups of European origin.

Therefore, the contributions of this article to the literature on ethnic discrimination are the following. We show that (i) ethnic discrimination in Russia is mostly directed against groups of Southern origin, with not much discrimination against groups of European origin (ethnic hierarchy); (ii) men from ethnic minorities face stronger discrimination compared with women; and (iii) the pattern and extent of ethnic discrimination differ across locations with varying ethnic composition of the populations and the history of ethnic inter-group relations. These findings contribute to the literature on the inter-group distance and contact hypothesis showing how the history of inter-group contact and institutional arrangements can mitigate the sense of ethnic group threat.

\section{Ethnic Hierarchies, Discrimination, and Local Context}

Human societies tend to be organized as group-based hierarchies (Sidanius and Pratto, 2001). Many modern societies are multi-racial and multi-ethnic and include large ethnic minorities, often both indigenous and of immigrant origin. Researchers of inter-group social distance argue that social status varies across racial and ethnic groups. In many Western societies North Europeans have the highest status, followed by South and Eastern Europeans, Asians, and Africans (Hagendoorn, 1995). This ethnic hierarchy can be stable across time (Kleg and Yamamoto, 1998; Ford, 2011) and is often accepted both by the ethnic majority and by minorities (Verkuyten, Hagendoorn and Masson, 1996; Zick et al., 2001), although some ethnic boundaries can blur over time (Alba, 2005). Survey evidence confirms that attitudes of natives towards immigrants of different ethnic origin can vary strongly. Ethnic stereotypes are group specific. In the United States, respondents rate White Americans higher than Asians, and Asians higher than African Americans and Hispanics, on most traits (Bobo and Massagli, 2001). The British public accepts immigrants from Australia, but many are more sceptical about Europeans, and especially immigrants from Africa, the Caribbean region and South Asia (Ford, 2011).

Correspondence studies have mostly been interpreted as attempts to measure discrimination in the labour market. As most experiments, they often lack external validity and generalizability (Baldassarri and Abascal, 2017). By design, these studies are limited to only a few occupations, skills, locations, racial and ethnic groups, and channels of recruitment. In most cases, we can only collect data about invitations to interviews rather than actual job and wage offers. Extrapolating experimental estimates of discrimination in recruitment to other areas of the labour market requires us to make many assumptions. Theoretically, correspondence studies mostly contributed to separating statistical from taste-based discrimination and have been detached from the literature exploring the group threat and contact hypotheses that often underpin the sociological studies of the attitudes towards immigrants. However, correspondence tests can also be seen as a tool for measuring groupspecific ethnic prejudice, as revealed in employers' hiring decisions. While not coming from nationally representative samples, experimental studies of ethnic prejudice have the important advantage of minimizing social desirability bias. The focus of research then shifts, from providing unbiased estimates of labour market discrimination, to examining the relative standings of racial and ethnic groups.

Most correspondence studies only involved one or two ethnic minority groups and were not designed to measure group variation in discrimination. When multiple groups were involved the results often showed that in Western countries minorities of European origin were 
treated preferentially compared with minorities of nonEuropean origin (Baldini and Federici, 2011; Booth, Leigh and Varganova, 2012; Carlsson and Eriksson, 2015; Acolin, Bostic and Painter, 2016; Baert et al., 2017; Lancee, 2019; Vernby and Dancygier, 2019). These findings confirm the existence of an ethnic hierarchy in the labour market and are consistent with the social distance research, and survey evidence of ethnic differences in employment and wages (Heath and Cheung, 2007). Not all minorities are the same, and some are treated better than others.

Blumer (1958) famously suggested that racial prejudice emerges when members of the dominant group perceive a challenge, to their superior social status, from subordinate out-groups. The group threat hypothesis became one of the pillars of the literature on attitudes towards immigrants (Ceobanu and Escandell, 2010). Empirically, it is often tested by looking at the association between prejudice and real or perceived immigrant group size, possibly mediated by economic conditions (Quillian, 1995; Semyonov, Raijman and Gorodzeisky, 2006). Majority members may feel more threatened in places with a higher proportion of ethnic minority members, especially when the economy is poor. The support, from empirical survey evidence, of the group threat hypothesis has been mixed. When the analysis is conducted at the regional rather than the country level, some studies confirm the association between minority group size and anti-immigrant prejudice in Europe (Markaki and Longhi, 2013), whereas others fail to find this link (Hjerm, 2009; Rustenbach, 2010).

Another well-established theoretical approach that is often discussed in this literature is the contact hypothesis (Allport, 1954). Under certain conditions, experiencing positive contact with members of out-groups may reduce prejudice (Pettigrew and Tropp, 2006). While the group threat and contact theories may generate contradictory predictions, they both stress the importance of contextual factors for inter-group relations. Both theories imply that the level of discrimination would vary across locations with different racial and ethnic population compositions. More ethnically diverse places may stimulate inter-group contact that will reduce prejudice. On the other hand, the influx of ethnically different populations may trigger the sense of group threat and provoke negative attitudes towards newcomers. Correspondence studies showed that in some places (France, London) housing discrimination against minorities was stronger in locations with more immigrants (Carlsson and Eriksson, 2015; Acolin, Bostic and Painter, 2016), whereas in others (Sweden) the effect was in the opposite direction (Carlsson and Eriksson, 2014).

The population share of ethnic minorities is a rather crude measure of group threat, and can sometimes be misleading. In his famous essay, Blumer (1958) notes that group position is a historical product and is set by the conditions of initial contact. When looking at the association between the ethnic composition of a population and the level of prejudice it is important to consider the historical origins of ethnically diverse locations. Ethnically mixed populations may emerge as a result of migration when minority groups, often with a lower status in the ethnic hierarchy, move to a territory already populated by the dominant group, as in the case of the slave trade in Americas (forced migration) or modern immigration to Western countries. Most existing studies of discrimination analysed it in the context of ethnic heterogeneity historically produced by immigration. Another historical cause of ethnically mixed locations is conquest and colonization, when a dominant group subjugates a territory with an ethnically distinct population. The European colonization of Asia, Africa, and the Americas produced many racially and ethnically heterogeneous populations across the world. Some ethnically mixed regions in Europe are also products of earlier colonization (Wales and Northern Ireland in the United Kingdom, the Basque country in Spain). Perceptions of group threat may be different in places where ethnic heterogeneity originated from earlier colonization by a high-status group and where the indigenous group maintains its ethnic identity. We use this observation in our research design.

\section{The Russian Context}

According to the most recent census, in 2010, ethnic Russians constitute about 80 per cent of Russia's population (Rosstat, 2012). The other 20 per cent, or 26 million people, describe themselves as not ethnically Russian and belong to over 100 ethnic groups. This ethnic heterogeneity reflects the history of the Russian state and is a result both of conquest and colonization (by ethnic Russians, of territories with indigenous populations) and of immigration of ethnic minorities to Russia's heartlands.

The Grand Duchy of Moscow that originally occupied a relatively small territory in what is known now as the Central European Russia and was populated predominantly by Orthodox Slavs, started a rapid territorial expansion in the 15th century. By the 18th century, when the Russian state became an empire, it acquired vast territories in the Volga river basin, the Urals, 
Ukraine, and Siberia, populated by indigenous ethnic groups (Riasanovsky, 2000). By the time of the First World War and the 1917 revolution, the Russian empire was a multi-ethnic conglomerate where ethnic Russians constituted less than a half of the total population (Mironov, 2017). After the Soviet Union was founded in 1922, the Bolsheviks had a debate about the 'nationalities question' in Soviet Russia. Eventually, they rejected the orthodox Marxist approach that denied the significance of ethnic identities, and adopted the 'great danger' concept that argued Russian chauvinism was a greater danger compared with local ethnic nationalisms. The political implication of this approach was the adoption of a policy intended to promote local ethnic identities and accelerate the social, economic, and cultural development of 'backward' ethnic groups (Vujacic, 2007), in what was called in the literature the 'affirmative action empire' (Martin, 2001). The Soviet state introduced ethnic quotas in universities and governmental organizations, promoted ethnic elites, established language schools, printed books and newspapers in local languages, and supported intellectuals from ethnic minorities (Slezkine, 1994; Hirsch, 1997, 2000). The 'affirmative action empire' policy was revoked in the mid-1930s and many ethnic groups later suffered from state repression and forced deportations. However, some of the institutions adopted in this early period stayed in place and continue to affect Russia's ethnic policies until now.

According to the 1936 Constitution, the Soviet Union was organized as a nested hierarchy of administrative units (Tishkov, 1997). At the highest level, there were 11 (later 15) Soviet socialist republics; the Russian Federation was one of them. Russia further consisted of autonomous Soviet republics in the territories populated by the largest ethnic minorities, provinces (oblasts) in the ethnic Russian heartlands, and territories (krays) in the colonized territories with ethnically mixed populations. Krays included ethnic autonomous oblasts, populated by smaller ethnic groups. With some changes, this structure, based on the principles of ethnic federalism, remained in place until the disintegration of the USSR, and was inherited by modern Russia.

In contemporary Russia, among 85 'federation subjects', there are 22 ethnic republics and 4 ethnic autonomous districts. Most republics have a 'titular' ethnic group (or in some cases two groups) that is usually reflected in their names (e.g. Tatarstan for the republic of Volga Tatars). The population share belonging to titular ethnic groups varies across the republics. Chechens are 95 per cent of Chechnya's population, whereas in the northern republic of Karelia, the Karels (a Finno-Ugric people) constitute only 7 per cent of residents. The language of the titular ethnic group is usually recognized, in each of the republics, as an official language in addition to Russian. The extent to which indigenous languages are actually used in everyday life varies, but most republics have print media and TV and radio broadcasting in the languages of titular groups. Titular languages are taught in schools, although examinations have to be taken in Russian. Many republics still keep the Soviet institutions that were originally designed to produce native ethnic intelligentsia (such as local Academies of Sciences, etc.; Gorenburg, 2003; Giuliano, 2011). The system of ethnic quotas in the government and employment is no longer in place, but the 'nativization' of local cadres remains at approximately the same level as in the late Soviet period (Shcherbak and Sych, 2017).

In addition to the conquest of new lands, another source of Russia's ethnic heterogeneity has been voluntary or forced migration of ethnically non-Russian groups. Small communities of foreign craftsmen, merchants and soldiers had lived in Moscow since the Middle Ages, but the first mass migration occurred in the 18th century, when Catherine the Great invited colonists from Germany into Russia. About 40,000 came, mostly settling in the Volga river region and modern Eastern Ukraine (Mironov, 2014). By 1914, over 1 million ethnic Germans moved to the Russian empire (Osinsky, 1928). WWI and the 1917 revolution marked the end of the Pale of Settlement (a law that banned Jews from settling outside the western parts of the empire), and thereafter many Jews moved to the cities in Central Russia. By the time of the 1926 census, they constituted 6 per cent of Moscow's and 5 per cent of Leningrad's populations, being the second largest ethnic group in both cities after ethnic Russians (Perepis, 1928). Rapid industrialization and urbanization in the Soviet period stimulated internal migration. Soviet colonization of the Urals and Siberia involved many ethnic groups, leading to ethnically heterogeneous populations in Siberian urban centres.

The collapse of the USSR in 1991 led to further population flows. Ethnic Russians started to return to Russia from the former Soviet republics that became independent states. Following ethnic wars and the deterioration of the economic situation in the Caucasus in the early 1990s, many Armenians, Azerbaijanis, and Georgians moved to Russia. These migration flows are hard to quantify, but between the 1989 and 2002 censuses the Armenian population of Russia increased from 0.5 million to 1.1 million people. Russia's economic recovery, that started in the early 2000s, stimulated new 
waves of economic migration, mainly from Ukraine, Moldova, and Central Asia (Agadjanian, Menjívar and Zotova, 2017). Official statistics for the most recent immigration flows are poor, but in 2012 there were over 2 million Uzbek and over 1 million Tajik nationals in Russia, mainly employed in low-skilled occupations in the Moscow region and in other metropolitan areas. The number of Ukrainian passport-holders in Russia was 1.4 million in 2012, and it has significantly increased after the Russian-Ukrainian military conflict in 2014 (Bessudnov, 2016).

A number of previous studies used survey data to explore attitudes towards immigrants in Russia. Antiimmigrant sentiment is stronger in Russia than in most other European countries, whereas the explanatory power of the models that try to predict attitudes towards immigrants with the indicators of socio-economic position and the attitudinal variables is much lower (Gorodzeisky, Glikman and Maskileyson, 2015; Bessudnov, 2016), although explanations based on group threat and economic competition theories cannot be dismissed (Bahry, 2016). Ethnic Russians are on average more negative about immigrants than ethnic minorities (Gorodzeisky and Glikman, 2017), and the opposition towards immigration is often based on racial prejudice (Gorodzeisky, 2019). There is little evidence of a strong trend towards increasing or decreasing xenophobia between 1996 and 2012 (Chapman et al., 2018). In this article, we complement the survey evidence presented in this literature with experimental results.

The ethnic heterogeneity of Russia's population makes it an interesting case for studying ethnic hierarchies and discrimination. Russia has large ethnic minorities of both European origins (e.g. Germans, Jews, and Ukrainians) and non-European origins (e.g. Armenians, Chechens, Georgians, Tatars, and Uzbeks). There are religious differences as well; some groups are mostly Orthodox Christian (Armenians, Georgians, and Ukrainians), whereas others are Muslim (Azerbaijanis, Chechens, Tatars, and Uzbeks) or Buddhist (Kalmyks and Tuvans). Previous research into inter-ethnic social distance in Russia shows that Slavic minorities of Eastern European origin are placed higher in the ethnic hierarchy than minorities of Southern origin (Hagendoorn et al., 1998; Bessudnov, 2016). Another differentiating factor is the institutional status of minorities. Ethnic groups whose indigenous settlement area is within the Russian borders are usually titular, i.e. have the institutionalized privileged status in ethnic republics that they perceive as 'theirs' (Hagendoorn, Poppe and Minescu, 2008; Minescu, Hagendoorn and Poppe,
2008; Minescu and Poppe, 2011). Ethnic groups of immigrant origin do not have titular rights.

Our research design aims to employ these characteristics of the Russian case. First, we are interested in whether ethnic discrimination in the Russian labour market is group specific and follows an ethnic hierarchy, in which groups of European origin occupy a higher position than non-European groups. Second, we want to investigate if ethnic discrimination in employment is context dependent and varies between ethnically Russian regions and titular ethnic republics.

\section{Research Design}

\section{Ethnic Groups}

Table 1 shows characteristics of the ethnic groups that we included in the study. We selected groups of both European and non-European origin and both titular and non-titular groups.

We followed the standard practice of signalling ethnicity by randomly assigning ethnic names to CVs. We collected ethnic first names and surnames from a popular Russian social media website (examples of ethnic names are provided in the Supplementary Appendix).

To make sure that the names could be recognized as ethnic by employers, we conducted a survey. In the survey, we presented a list of names to respondents and asked them to assign the names to ethnic groups in an open-ended question, without providing a list of groups. We recruited a non-probability snowball sample on social media websites $(n=861)$. Compared with the general population, people in our sample were younger and more educated, more often female and Moscow and St. Petersburg were over-represented. Arguably this may better reflect demographic characteristics of urban HR employees than a national probability sample. ${ }^{1}$

The recognition of ethnic names varied by group (see Table 2). For four groups (ethnic Russians, Armenians, Georgians, and Ukrainians) respondents correctly identified the names in over 80 per cent of the cases. For all Muslim ethnic groups the identification rates were much lower. However, most respondents, even when unable to correctly identify the exact ethnic group for Muslim names, gave as an answer the name of another Muslim group. Muslim names have common origins and may indeed sound similar. For all ethnic minority groups, except Germans, the names were recognized as not ethnically Russian in over 95 per cent of cases. German names, arguably the most assimilated group in the list, were recognized as not ethnically Russian in 85 per cent of the answers. 
Table 1. Ethnic groups included in the study

\begin{tabular}{lrlll}
\hline Ethnic group & Size in Russia in $\mathbf{2 0 1 0}$ (thousand) & Region of origin & Dominant religion & Titular \\
\hline Ethnic Russians & 111,017 & European Russia & Orthodox Christian & No \\
Armenians & 1,182 & Caucasus & Orthodox Christian & No \\
Azerbaijanis & 603 & Caucasus & Muslim & In Chechnya \\
Chechens & 1,431 & North Caucasus & Muslim & No \\
Georgians & 158 & Caucasus & Orthodox Christian & No \\
Germans & 394 & Western Europe & Christian & No \\
Jews & 157 & Eastern Europe & Jewish & No \\
Latvians & 19 & Eastern Europe & Christian & No \\
Lithuanians & 31 & Eastern Europe & Christian & No \\
Tajiks & 200 & Central Asia & Muslim & In Tatarstan \\
Tatars & 5,311 & Volga region & Muslim & No \\
Ukrainians & 1,928 & Eastern Europe & Orthodox Christian & Muslim \\
Uzbeks & 290 & Central Asia & No &
\end{tabular}

Notes: Population size reported according to the 2010 Russian census. It underestimates the size of ethnic groups in the most recent immigration wave, in particular, Ukrainians, Tajiks, and Uzbeks.

Table 2. Recognition of ethnic names

\begin{tabular}{lllc}
\hline Ethnic group & Correct (\%) & Broadly correct $(\%)$ & Not Russian (\%) \\
\hline Georgian & 91 & 98 & 100 \\
Armenian & 90 & 96 & 100 \\
Russian & 88 & 90 & 12 \\
Ukrainian & 82 & 92 & 95 \\
Jewish & 72 & 84 & 99 \\
Tatar & 57 & 90 & 99 \\
German & 42 & 62 & 85 \\
Latvian & 35 & 65 & 100 \\
Lithuanian & 22 & 73 & 100 \\
Chechen & 20 & 83 & 99 \\
Uzbek & 19 & 91 & 100 \\
Azerbaijani & 16 & 90 & 100 \\
Tajik & 12 & 84 & 99
\end{tabular}

Notes: Broadly correct identification includes the following groups. For Russian and Ukrainian names any Slavic group; for Georgian and Armenian any group from the Caucasus; for Jewish and German Jews or Germans; for Latvian and Lithuanian any Baltic group; for Azerbaijani, Chechen, Tatar, Tajik, and Uzbek names any Muslim group, or generic 'Caucasus', or 'Central Asia'.

\section{Locations}

We conducted the experiment in four cities in Russia. Two cities, Moscow and St. Petersburg, are large metropolitan areas in European Russia with mostly ethnically Russian populations. The other two, Kazan and Ufa, are capitals of titular ethnic republics in the Volga river region. Table 3 provides information about the cities' populations and ethnic composition.

Moscow is Russia's capital, with a population of over 12 million people. According to the 2010 census, 92 per cent of the population are ethnically Russian. The census estimates are unlikely to include many people from the
Table 3. Characteristics of four locations

\begin{tabular}{|c|c|c|}
\hline City & $\begin{array}{l}\text { Population } \\
\text { (2017, thousand) }\end{array}$ & $\begin{array}{l}\text { Ethnic composition } \\
\text { (2010), per cent }\end{array}$ \\
\hline Moscow & 12,381 & $\begin{array}{l}\text { Russians (92) } \\
\text { Ukrainians (1.3) } \\
\text { Tatars (1.3) } \\
\text { Armenians (1) }\end{array}$ \\
\hline St. Petersburg & 5,282 & $\begin{array}{l}\text { Russians (92) } \\
\text { Ukrainians (1.5) } \\
\text { Belarusians }(0.9) \\
\text { Tatars }(0.7)\end{array}$ \\
\hline Kazan & 1,232 & $\begin{array}{l}\text { Russians (49) } \\
\text { Tatars (48) }\end{array}$ \\
\hline Ufa & 1,116 & $\begin{array}{l}\text { Russians (49) } \\
\text { Tatars (28) } \\
\text { Bashkirs (17) }\end{array}$ \\
\hline
\end{tabular}

Notes: Data on the population come from the estimates of the Russian Statistical Office. Data on the ethnic composition come from the 2010 census.

most recent immigration waves from the Caucasus, Central Asia, and Ukraine. In 2016, about 500,000 foreign workers had a work permit in Moscow and the Moscow region (Scherbakova, 2017). According to the census, the largest ethnic minorities in Moscow are Ukrainians, Tatars, Armenians, Azerbaijanis, and Jews. The largest groups in the recent immigration wave, unaccounted for in the census, are Tajiks and Uzbeks.

St. Petersburg, Russia's capital between 1712 and 1918 , is the second largest city in the country, with a population of over 5 million people. Over 90 per cent are ethnically Russian; the largest ethnic minorities are the same as in Moscow. 
Kazan is the capital of the ethnic republic of Tatarstan. In the 16th century, the Moscow state conquered the Khanate of Kazan, populated by groups of Turkic and Finno-Ugric origin (Romaniello, 2012). In the late imperial period, ethnic Russians were already a majority of the city's population; according to the 1897 census, 74 per cent of the inhabitants spoke Russian as their mother tongue and 22 per cent spoke Tatar. In 1920, the city became the capital of the Tatar Autonomous Socialist Republic, and Tatars-a predominantly Muslim ethnic group-acquired a titular status. In 2010, 49 per cent of the Kazan population was ethnically Russian, and 48 per cent Tatar.

Ufa is the capital of the Republic of Bashkortostan located to the east of Tatarstan, in the region between the Volga river and the Ural mountains. Bashkirs, the titular group, were a nomadic Muslim people who acknowledged the authority of the Russian tsar in the 16th century. Ufa was founded by Russian settlers in 1574, and for most of its history had a small ethnic Bashkir population. The Bashkir and Tatar languages are mutually intelligible, and the identity boundaries between these two groups have been fluid (Gorenburg, 1999). In 2010, Ufa had a 49 per cent ethnic Russian population, 28 per cent Tatars and 17 per cent Bashkirs. ${ }^{2}$

The choice of locations was driven by our research questions. We have two cities with predominantly ethnically Russian populations, located outside ethnic republics (Moscow and St. Petersburg). Two other cities (Kazan and Ufa) are capitals of titular ethnic republics, and in both cities ethnic Russians are about half of the population. Kazan and Ufa are also large enough (both have a population of over 1 million people) to simplify the logistics of the experiment. Kazan and Ufa are mostly Russian speaking (for several thousand applications submitted in these cities we only had one or two cases when an employer initiated a conversation in a local language while contacting applicants on the phone).

\section{Experimental Design}

The study was conducted on two most popular Russian job search websites, with monthly audiences of 3 and 10 million visitors (according to the Yandex.Radar data for May 2019). The job application process is similar on both websites. A person looking for a job creates an account on the website, completing the required fields. Then the job seeker can browse through vacancies advertised by firms, and apply online. After an application is made, firms gain access to the applicant's CV, and decide if they want to contact them. Contact can be made on the website or by phone.
We created accounts for applicants in four cities and across four occupations: salesperson (low skilled, high customer contact); cook (low skilled, low customer contact); sales manager (high skilled, high customer contact); and computer programmer, specializing in 1C software ${ }^{3}$ (high skilled, low customer contact). Each account was randomly assigned gender and an ethnic name. Creating accounts was a time-consuming process that could not be automated. At this stage, we reduced the number of ethnic groups to 10 , combining several groups pairwise: Azerbaijanis and Chechens (both Muslim groups from the Caucasus); Latvians and Lithuanians (Baltic groups); and Tajiks and Uzbeks (Muslim Central Asian groups). Our survey shows that, for these groups, employers are unlikely to identify the names precisely, although most will be able to attribute them to broader regions.

Thus we have a full factorial design, with two treatments, ethnicity (10 levels) and gender (2 levels), and two strata, city (4 levels) and occupation (4 levels). This required the creation of 320 online accounts, 160 on each website (selected to constitute a fractional factorial design on each website; Lawson, 2015). For each ethnic group, we have 32 names (16 male and 16 female). This is considerably more than in most previously conducted experiments, reducing idiosyncratic name effects (Gaddis, 2017). Name was the only signal of ethnicity. All job applicants were presented as Russian nationals in the age range 28-35 years, with Russian as their mother tongue. We assigned to them educational credentials from vocational schools and universities in the city of job application, and local mobile telephone numbers. For all applicants we provided previous experience for the last 7 years (two fictitious jobs in the same city). No information about marital status or the number of children was included. Applications were submitted by filling forms on the websites that included several other mandatory questions, such as knowledge of foreign languages (we added English for sales managers and computers programmers, but not for cooks and sales persons), having a driving licence ('yes' for sales managers and programmers, 'no' for cooks and sales persons), skills, responsibilities in both previous jobs and personal information (e.g. 'I am an enthusiastic and easy going person'). For skills, responsibilities, and personal information, we randomly chose several bullet points for each candidate from the preprepared occupation-specific lists.

Prior to the main study, but after a pilot study (that involved sending 1,000 job applications), we conducted power analysis with the following assumptions: effect size of 0.2 (corresponding approximately to the difference between 40 per cent and 30 per cent contact rate); intraclass correlation of 0.01 where names were treated 
Table 4. Contact rates by ethnic group and location

\begin{tabular}{|c|c|c|c|c|c|c|}
\hline Ethnic group & $n$ applications & $n$ response & Proportion contacted & $95 \%$ confidence interval & Call-back ratio & Odds ratio \\
\hline \multicolumn{7}{|l|}{ Moscow and St. Petersburg } \\
\hline Russian & 616 & 254 & 0.41 & {$[0.35 ; 0.47]$} & 1 & 1 \\
\hline Ukrainian & 559 & 220 & 0.39 & {$[0.34 ; 0.45]$} & 1.05 & 0.92 \\
\hline Jewish & 604 & 237 & 0.39 & {$[0.35 ; 0.44]$} & 1.05 & 0.92 \\
\hline German & 642 & 232 & 0.36 & {$[0.32 ; 0.40]$} & 1.14 & 0.81 \\
\hline Latvian and Lithuanian & 551 & 185 & 0.34 & {$[0.29 ; 0.38]$} & 1.23 & 0.72 \\
\hline Tatar & 610 & 170 & 0.28 & {$[0.23 ; 0.32]$} & 1.48 & 0.55 \\
\hline Tajik and Uzbek & 570 & 159 & 0.28 & {$[0.22 ; 0.34]$} & 1.48 & 0.55 \\
\hline Azerbaijani and Chechen & 598 & 165 & 0.28 & {$[0.23 ; 0.32]$} & 1.48 & 0.54 \\
\hline Armenian & 610 & 163 & 0.27 & {$[0.22 ; 0.31]$} & 1.54 & 0.52 \\
\hline Georgian & 549 & 142 & 0.26 & {$[0.21 ; 0.30]$} & 1.59 & 0.50 \\
\hline \multicolumn{7}{|l|}{ Kazan and Ufa } \\
\hline Jewish & 384 & 187 & 0.49 & {$[0.42 ; 0.55]$} & 0.90 & 1.24 \\
\hline German & 369 & 167 & 0.45 & {$[0.38 ; 0.53]$} & 0.96 & 1.08 \\
\hline Russian & 402 & 174 & 0.43 & {$[0.38 ; 0.49]$} & 1 & 1 \\
\hline Tatar & 343 & 147 & 0.43 & {$[0.36 ; 0.49]$} & 1.01 & 0.98 \\
\hline Ukrainian & 365 & 155 & 0.42 & {$[0.38 ; 0.47]$} & 1.02 & 0.97 \\
\hline Tajik and Uzbek & 373 & 150 & 0.40 & {$[0.34 ; 0.46]$} & 1.08 & 0.88 \\
\hline Georgian & 368 & 144 & 0.39 & {$[0.31 ; 0.47]$} & 1.11 & 0.84 \\
\hline Armenian & 378 & 148 & 0.39 & {$[0.34 ; 0.44]$} & 1.11 & 0.84 \\
\hline Latvian and Lithuanian & 355 & 138 & 0.39 & {$[0.33 ; 0.44]$} & 1.11 & 0.83 \\
\hline Azerbaijani and Chechen & 361 & 138 & 0.38 & {$[0.32 ; 0.44]$} & 1.13 & 0.81 \\
\hline
\end{tabular}

Notes: Groups ordered by the contact rate within each pair of locations. $95 \%$ CI stands for $95 \%$ confidence interval, calculated after adjusting standard errors for cluster-design effects (Green and Vavreck, 2007). Call-back ratio was calculated as the proportion of responses for ethnic Russians divided by the proportion of responses for an ethnic group. Odds ratios were calculated as the odds of receiving a response, for an ethnic group, divided by the odds of receiving a response for ethnic Russians.

as clusters (this value was determined by the pilot study); 95 per cent statistical significance level; and power of 80 per cent. With these assumptions, we required a sample size of about 8,000 in order to obtain reliable estimates for 10 ethnic groups, interacted with a factor with two levels (such as sex or pairwise combinations of cities or occupations).

Data were collected between June 2017 and January 2018. We employed six research assistants who monitored the websites, sent job applications, and recorded contact made by employers on the websites or on the phone. When employers contacted applicants on the phone, research assistants were instructed to politely decline invitations to job interviews.

\section{Results}

\section{Contact Rates by Ethnic Group and Location}

Overall, we submitted 9,607 job applications. In 36 per cent of the cases, employers invited applicants for an interview, either by contacting them on the phone (21 per cent) or on the website (23 per cent), with some employers using both communication channels. Table 4 reports contact rates by ethnic group. This is shown separately for Moscow and St. Petersburg-on the one hand-and Kazan and Ufa on the other. Figure 1 shows this information as a dot plot with 95 per cent confidence intervals. We do not have enough statistical power to report estimates in four cities separately, but the patterns are similar in Moscow and St. Petersburg, and in Kazan and Ufa (see Supplementary Appendix for details). Table 5 presents linear probability models for being contacted by employers that control for all the other characteristics of applications (gender, occupation, city, website, and research assistant) and test for statistical significance of the differences from the reference group, ethnic Russians.

In Moscow and St. Petersburg, the in-group, ethnic Russians, have the highest contact rate-41 per cent. Applicants with Ukrainian, Jewish, and German names have only slightly, and not statistically significantly, lower contact rates. On the other hand, all ethnic groups of non-European Southern origin have significantly lower contact rates, ranging from 26 per cent 


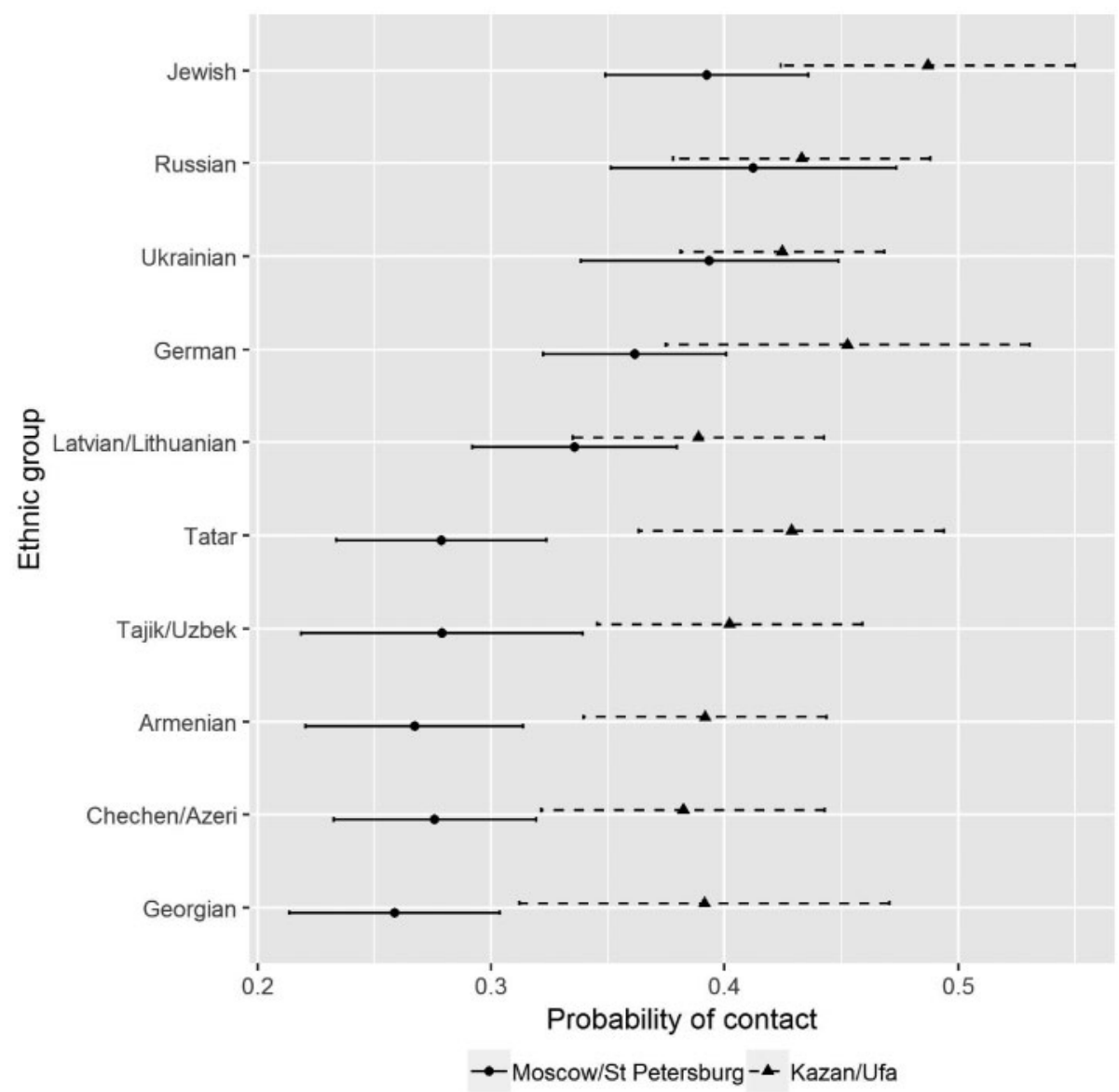

Figure 1. Contact rates by ethnic group and location.

(Georgians) to 28 per cent (Tatars). Applicants with Latvian and Lithuanian names are in the middle of the list, with a contact rate of 34 per cent. We observe a clear ethnic hierarchy in hiring, where all groups of European origin are given preference compared with Southern groups of non-European origin, most of whom are visible minorities.

In Kazan and Ufa, the response rates are higher than in Moscow and St. Petersburg across all the ethnic groups. This reflects characteristics of the local labour markets. In contrast to the results in Moscow and St. Petersburg, in Kazan and Ufa none of the differences in the contact rates between ethnic Russians and other ethnic groups is large or statistically significant. Jewish and German applicants have the highest contact rates, closely followed by ethnic Russians and Tatars, who are contacted by employers with equal frequency. The difference between ethnic Russians and Tatars, on the one hand, and other groups of Southern origin, on the other hand, is only between 2 and 5 percentage points, and not statistically significant. The overall ethnic hierarchy, though, is similar to Moscow and St. Petersburg, and most groups of European origin are contacted more often than most groups of Southern origin, even if the differences in contact rates are smaller.

Overall, we find substantial differences in the ethnic preferences of employers between Moscow and St. Petersburg, on the one hand, and Kazan and Ufa, on the other. In the former, there is strong discrimination against all non-ethnically Russian groups of Southern origin. In the latter, discrimination is much weaker, to the extent that-given our sample size-we cannot be sure that it exists in the population.

\section{Gender Differences in Contact Rates across Ethnic Groups}

Do men and women of ethnic minority origin experience discrimination to the same extent? To answer this 
Table 5. Linear probability models of being contacted by employers

\begin{tabular}{|c|c|c|}
\hline & \multicolumn{2}{|c|}{$\begin{array}{l}\text { Dependent variable: contacted } \\
\text { by employer }\end{array}$} \\
\hline & $\begin{array}{l}\text { Moscow/ } \\
\text { St. Petersburg (1) }\end{array}$ & $\begin{array}{l}\text { Kazan/ } \\
\text { Ufa (2) }\end{array}$ \\
\hline \multicolumn{3}{|l|}{$\begin{array}{l}\text { Ethnic group } \\
\quad \text { (ref.: ethnic Russians) }\end{array}$} \\
\hline Jewish & $\begin{array}{l}-0.02 \\
(0.04)\end{array}$ & $\begin{array}{c}0.06 \\
(0.04)\end{array}$ \\
\hline Ukrainian & $\begin{array}{c}-0.02 \\
(0.03)\end{array}$ & $\begin{array}{r}0.002 \\
(0.04)\end{array}$ \\
\hline German & $\begin{array}{l}-0.05 \\
(0.03)\end{array}$ & $\begin{array}{c}0.04 \\
(0.04)\end{array}$ \\
\hline Latvian/Lithuanian & $\begin{array}{c}-0.07 * \\
(0.03)\end{array}$ & $\begin{array}{l}-0.04 \\
(0.04)\end{array}$ \\
\hline Tatar & $\begin{array}{l}-0.13 * * * \\
(0.03)\end{array}$ & $\begin{array}{r}0.005 \\
(0.04)\end{array}$ \\
\hline Tajik/Uzbek & $\begin{array}{l}-0.13 * * * \\
(0.03)\end{array}$ & $\begin{array}{l}-0.03 \\
(0.04)\end{array}$ \\
\hline Azerbaijani/Chechen & $\begin{array}{l}-0.13 * * * \\
(0.03)\end{array}$ & $\begin{array}{l}-0.04 \\
(0.04)\end{array}$ \\
\hline Armenian & $\begin{array}{l}-0.14 * * * \\
(0.03)\end{array}$ & $\begin{array}{l}-0.03 \\
(0.04)\end{array}$ \\
\hline Georgian & $\begin{array}{l}-0.15 * * * \\
(0.03)\end{array}$ & $\begin{array}{l}-0.03 \\
(0.04)\end{array}$ \\
\hline Observations & 5,909 & 3,698 \\
\hline
\end{tabular}

Notes: Linear probability models; standard errors in parentheses. The dependent variable is binary ( 1 if contacted by employer, 0 if not). All models control for gender, occupation, city, website, and research assistant's name (coefficients not shown). Cluster-robust standard errors applied (clustered by applicant's name). Ethnic Russians are the reference group.,

$* P<0.05 ; * * P<0.01 ; * * P<0.001$.

question, we fit regression models with interaction effects between ethnicity and gender. Our sample size is not large enough to allow for the analysis at the level of individual ethnic groups (split by location) and we combine all ethnic groups into two categories: of European origin (Germans, Jews, Latvians and Lithuanians, ethnic Russians, and Ukrainians) and of non-European origin (Armenians, Azerbaijanis and Chechens, Georgians, Tajiks and Uzbeks, and Tatars). The results are reported in Table 6 .

In Moscow and St. Petersburg, discrimination against men of Southern origin is stronger compared with discrimination against women, and the difference is statistically significant. On average, female applicants from Southern groups are contacted 7 percentage points less often than female applicants from European groups. For male applicants the difference is 14 percentage points. In Kazan and Ufa, we do not find strong evidence of discrimination, and the interaction effect
Table 6. Interaction between ethnicity and gender

Dependent variable: contacted by employer

Moscow/ Kazan/Ufa (2)
St. Petersburg (1)

St. Petersburg (1)

$\begin{array}{llc}\begin{array}{l}\text { Ethnic group } \\ \text { (ref.: European) }\end{array} & & \\ \text { Southern } & -0.07 * * * & -0.02 \\ & (0.02) & (0.02) \\ \text { Gender (ref: female) } & & \\ \text { Male } & 0.0001 & 0.01 \\ & (0.02) & (0.03) \\ \text { Southern } \times \text { male } & -0.07 * & -0.03 \\ & (0.03) & (0.03) \\ \text { Observations } & 5,909 & 3,698\end{array}$

Notes: Linear probability models; standard errors in parentheses. All the models control for occupation, city, website, and research assistant's name (coefficients not shown). Cluster-robust standard errors applied (clustered by applicant's name). Groups of European origin and women are the reference groups. European origin includes Germans, Jews, Latvians and Lithuanians, ethnic Russians, and Ukrainians. Non-European origin includes Armenians, Azerbaijanis and Chechens, Georgians, Tajiks and Uzbeks, and Tatars., $* P<0.05 ; * P<0.01 ; * * P<0.001$.

between ethnicity and gender is smaller and not statistically significant.

We conducted a similar analysis for the interaction between ethnicity and occupation, and did not find much evidence that ethnic hierarchies vary across occupations in Moscow and St. Petersburg. In Kazan and Ufa, cooks from Southern groups had about the same contact rates as European groups, whereas for skilled occupations (sales manager and computer programmer) the contact rates for Southern groups were lower than for European groups. The details of the analysis are available in the Supplementary Appendix.

\section{Contact on the Phone and on the Websites}

In this section, we analyse the communication channels that employers used for contacting applicants. They could do this either on the websites (by sending a message asking an applicant to contact them) or by making a call to an applicant's mobile phone. By sending a message through the websites employers could avoid initiating a personal conversation with an applicant on the phone. Table 7 reports models that look at the probability of receiving a phone call as opposed to not receiving a call, for those applications that got a positive response.

In Moscow and St. Petersburg, all ethnic groups are less likely to be contacted on the phone, compared with ethnic Russians. The effect is statistically significant 
Table 7. Contact on the phone and on the websites

\begin{tabular}{|c|c|c|}
\hline & \multicolumn{2}{|c|}{$\begin{array}{l}\text { Dependent variable: contacted } \\
\text { on the phone }\end{array}$} \\
\hline & $\begin{array}{l}\text { Moscow/ } \\
\text { St. Petersburg (1) }\end{array}$ & $\begin{array}{l}\text { Kazan/ } \\
\text { Ufa (2) }\end{array}$ \\
\hline \multicolumn{3}{|l|}{$\begin{array}{l}\text { Ethnic group } \\
\quad \text { (ref.: ethnic Russians) }\end{array}$} \\
\hline Jewish & $\begin{array}{l}-0.11 * \\
(0.05)\end{array}$ & $\begin{array}{l}-0.07 \\
(0.04)\end{array}$ \\
\hline Ukrainian & $\begin{array}{l}-0.07 \\
(0.05)\end{array}$ & $\begin{array}{l}-0.01 \\
(0.05)\end{array}$ \\
\hline German & $\begin{array}{l}-0.12 * \\
(0.06)\end{array}$ & $\begin{array}{c}0.06 \\
(0.04)\end{array}$ \\
\hline Latvian/Lithuanian & $\begin{array}{l}-0.17 * * \\
(0.06)\end{array}$ & $\begin{array}{l}-0.03 \\
(0.05)\end{array}$ \\
\hline Tatar & $\begin{array}{l}-0.18 * * \\
(0.06)\end{array}$ & $\begin{array}{l}-0.02 \\
(0.07)\end{array}$ \\
\hline Tajik/Uzbek & $\begin{array}{l}-0.22 * * * \\
(0.05)\end{array}$ & $\begin{array}{l}-0.10 \\
(0.05)\end{array}$ \\
\hline Azerbaijani/Chechen & $\begin{array}{l}-0.19 * * * \\
(0.05)\end{array}$ & $\begin{array}{l}-0.01 \\
(0.06)\end{array}$ \\
\hline Armenian & $\begin{array}{l}-0.16 * * \\
(0.06)\end{array}$ & $\begin{array}{l}-0.02 \\
(0.04)\end{array}$ \\
\hline Georgian & $\begin{array}{l}-0.17 * * \\
(0.06)\end{array}$ & $\begin{array}{l}-0.02 \\
(0.05)\end{array}$ \\
\hline Observations & 1,927 & 1,548 \\
\hline
\end{tabular}

Notes: Linear probability models; standard errors in parentheses. The sample includes only applications that received a positive response. The dependent variable is 1 if contact was made on the phone and 0 if the phone was not used. The models control for gender, occupation, city, website, and research assistant's name. Cluster-robust standard errors applied (clustered by applicant's name). Ethnic Russians are the reference group., * $P<0.05 ; \quad$ * $P<0.01 ; \quad$ *** $P<0.001$.

for all groups, except Ukrainians. Even Germans and Jews, two groups that overall are contacted by employers about as often as ethnic Russians, are considerably less likely to receive a phone call (by 11 and 12 percentage points). For all the Muslim groups, the effect is even stronger, and the difference from the phone contact rate with ethnic Russians reaches about 20 percentage points. In Moscow and St. Petersburg many employers try to avoid initiating phone conversations with the members of out-groups, especially Muslim groups of Southern origin. In contrast, in Kazan and Ufa the differences in phone contact rates across ethnic groups are much smaller and none of them is statistically significant at the 95 per cent level.

On the websites, employers could send an optional rejection message to unsuccessful applicants. The message was automatic, impersonal, and only required employers to press a rejection button. We interpret sending a message as a stronger signal of rejection. In Moscow and St. Petersburg, the probability of being explicitly rejected is higher for groups of Southern origin (except Tatars) compared with ethnic Russians. We do not observe this effect in Kazan and Ufa. The details of the analysis are available in Supplementary Appendix.

\section{Discussion}

In this article, we answer three questions. First, our findings confirm the predictions derived from the literature on social dominance and ethnic hierarchies (Hagendoorn, 1995; Sidanius and Pratto, 2001) showing that the ethnic preferences of Russian employers are structured according to an implicit ethnic hierarchy, with groups of European origin preferred to groups of Southern origin. Our second finding speaks to the literature on intersectionality showing that the strength of discrimination against Southern groups varies by gender, with men from ethnic minority groups experiencing stronger prejudice than women. Finally, we contribute to the study of the group threat and contact hypotheses, showing that ethnic discrimination can vary across places with different ethnic structures of the populations and the history of inter-group contacts. We will now discuss these results separately.

In Moscow and St. Petersburg, we find a clear pattern of ethnic discrimination in the job market. Applicants from the groups of European origin receive preferential treatment compared with the groups of Southern origin. As predicted by the theory of ethnic hierarchies, the in-group, ethnic Russians, has the highest contact rate. The contact rates for some other groups of European origin (Germans, Jews, and Ukrainians) are similar to those for ethnic Russians, and the differences between these groups are not statistically significant.

Some of these findings may seem surprising. Antisemitism, both in the general population and in state policies, was a feature of Jewish life in the late Soviet Union, and Jews were discriminated against in higher education and in a number of white-collar occupations (Pinkus, 1990). The Soviet Union's collapse in 1991 was followed by large-scale Jewish immigration to Germany, Israel, and the United States. In the 1990s and 2000s, state discrimination against Jews disappeared, and antisemitism in Russian society became less pronounced. In a 2015 survey, only 8 per cent of Russians expressed negative attitudes towards Jews (Levada, 2016; Levinson, 2016). Our results confirm these findings.

We collected data in 2017, 3 years after the beginning of the Russian-Ukrainian military conflict that 
resulted in the annexation of the Crimea and the establishment of pro-Russian military regimes in parts of Eastern Ukraine. The Russian state media closely followed the conflict, with a largely anti-Ukrainian stance. Ukrainian names were well recognized in the survey we conducted. Yet, we do not find evidence of discrimination against Ukrainians, who were contacted by employers about as often as ethnic Russians. Perhaps the explanation is that many ethnic Russians do not see Ukrainians as being from a separate nation and, therefore, do not perceive them as an out-group. Their views on the Ukrainian state are more negative than on the Ukrainian people. In a survey conducted in 2015 in Russia, 43 per cent said that there was no difference at all between ethnic Russians and Ukrainians, and another 35 per cent said the differences were minor. Only 3 per cent reported negative attitudes towards Ukrainians (64 per cent reported positive attitudes; Public Opinion Foundation, 2015).

For all the groups of Southern origin, the contact rates in Moscow and St. Petersburg are much lower than for ethnic Russians. Among the Southern groups, there is little difference in the contact rates. Partly this can be explained by the inability of HR employees to differentiate between the names of different Muslim groups (as shown in our pre-experiment survey). However, two Christian ethnic groups from the Southern Caucasus, with members whose names are easily recognized by Russians (Armenians and Georgians), have contact rates that are as low as for the Muslim groups. These results show that religion is not the main factor that structures Russia's ethnic hierarchy. The groups of European origin who are not visible minorities, and are more culturally Russified (or at least are perceived by ethnic Russians as Russified) are rarely discriminated against. In contrast, visible minorities from the South (both Muslim and Christian) are perceived as out-groups and are treated more negatively.

How strong is ethnic discrimination in Russia compared with other countries? In Moscow and St. Petersburg, the odds ratio for all Southern groups compared with ethnic Russians ranged between 0.5 and 0.57 . In a recent meta-analysis (Zschirnt and Ruedin, 2016), the average odds ratio across 34 correspondence tests conducted in Western countries was 0.6. In a famous US study (Bertrand and Mullainathan, 2004), the odds ratio for African American versus White job applicants was 0.59. Ethnic discrimination in Moscow and St. Petersburg appears to be close to these estimates. Note that the signal of ethnicity in our study is relatively weak: we only randomize applicants' names and indicate that all applicants are Russian nationals and native
Russian speakers. We do not include photographs in the applications. This makes our estimates of discrimination more conservative. In reality, job applicants from ethnic minorities, who sometimes speak Russian with an accent and are not Russian citizens, may face stronger discrimination at the stage of recruitment.

With respect to the interaction between ethnicity and gender, male applicants from discriminated ethnic groups achieve lower contact rates than female applicants. This is consistent with the results from some other experimental studies (Arai, Bursell and Nekby, 2016; Liebkind, Larja and Brylka, 2016; Vernby and Dancygier, 2019) and contradicts the 'double disadvantage' (or intersectionality) hypothesis (Browne and Misra, 2003). ${ }^{4}$ According to a meta-analysis of 37 correspondence tests, white men receive 63 per cent more callbacks compared with ethnic minority men, whereas the gap for women is 52 per cent (Quillian and Nanni, 2018). In the social dominance literature, this is known as the subordinate male target hypothesis; this postulates that ethnic discrimination is directed primarily against men from out-groups (Sidanius and Veniegas, 2000; Sidanius and Pratto, 2001). While we do not have data to test this empirically, it is likely that in Russia ethnic minority men are perceived by employers as more threatening than women. Russia's post-Soviet history has seen several ethnic riots that all started after street altercations between young ethnically Russian men and migrants from the Caucasus (Foxall, 2014; Arnold, 2018), and popular stereotypes about men from Southern ethnic groups are often related to impulsiveness and aggression (Bodrunova et al., 2017).

Perhaps the most intriguing finding of the study is the difference in ethnic discrimination between Moscow and St. Petersburg, on the one hand, and Kazan and Ufa, on the other hand. In contrast to the findings in Moscow and St. Petersburg, in Kazan and Ufa we do not find much variation in the contact rates across all ethnic groups. In both cities (Kazan and Ufa), ethnic Russians and Tatars are the two largest ethnic groups, and the contact rates for them are very similar. The rates are lower for other groups of Southern origin, but the difference from ethnic Russians and Tatars is small (odds ratios vary between 0.81 and 0.93 ) and not statistically significant. We believe that this is a unique case, as most previous experimental studies discovered discrimination against minority groups.

Why are the results in Kazan and Ufa different from those in Moscow and St. Petersburg? We only have four cities in this study, and have to combine them pairwise to increase statistical power. With, essentially, only two cases, we are therefore unable to conduct statistical 
analysis and make any generalizations. We can, however, discuss possible explanations that may be tested in future studies.

One possible explanation is the ethnicity of employers. Perhaps ethnically Russian employers discriminate on the basis of ethnicity and non-Russian employers do not. As Kazan and Ufa have a higher share of the nonRussian population this may reduce discrimination. We think that this is an insufficient explanation for our findings. Both in Kazan and Ufa, ethnic Russians are about 50 per cent of the population. We do not have data on their share among employers, but we were able to estimate the ethnic composition of the group of HR employees who responded to job applications (by coding their first names as ethnically Russian or non-Russian). In Kazan and Ufa, 28 and 23 per cent of the HR employees had non-ethnically Russian names, compared with 7 per cent in Moscow and 4 per cent in St. Petersburg. This suggests that ethnic Russians constitute a majority of employers in Kazan and Ufa. Besides, surveys suggest that at the national level the attitudes towards immigrants from the South, among Tatars, are only marginally more positive than among ethnic Russians (Bessudnov, 2016).

Another possible explanation is related to characteristics of the local labour markets. In Moscow and St. Petersburg, the labour markets are more competitive (overall, 33 per cent of the job applications received a positive response) compared with Kazan and Ufa (43 per cent). Perhaps employers have less space for discrimination when the job market is tight and there are fewer applicants. This is the argument proposed by Baert et al. (2015), who show with data from Belgium that discrimination against Turks only exists in occupations with a larger pool of candidates, and is absent in occupations where vacancies are more difficult to fill. However, this is not what we find in our study. In Moscow and St. Petersburg, cooks had a higher contact rate compared with other occupations, suggesting a less competitive job market for cooks, yet the level of discrimination is similar in all four occupations and is not lower for cooks (see Supplementary Appendix for details).

As in other countries, in Russia, the internet is only one of the channels for job search. Several studies that used data from the 1990s and early 2000s documented the importance of social networks and personal contacts in the Russian labour market (Yakubovich, 2005; Gerber and Mayorova, 2010). Since then job search mechanisms have evolved. While personal contacts remain important, in 201476 per cent of Russian firms and 49 per cent of job seekers ( 77 per cent in Moscow and St. Petersburg) used web sites for job search
(Roshchin, Solntsev and Vasilyev, 2017). In this respect, Russia is not very different from many Western countries. According to a 2017 survey, 53 per cent of respondents in Russia used internet job sites, compared with 37 per cent in the United States and 40 per cent in Germany (Sakurai and Okubo, 2017). While our experiment was only conducted on the internet, we would expect similar patterns of ethnic preferences to apply to other job search mechanisms (Pager, Bonikowski and Western, 2009) and more generally, other types of social interaction (housing and rental market, ethnic intermarriage, etc.).

One of our arguments, in this article, is that ethnic discrimination in the labour market is driven not so much by rational deliberation by employers, or by local labour market conditions, but rather by underlying ethnic stereotypes that are often implicit and have roots in the history of inter-group relations. We believe that the case of Kazan and Ufa can be better explained by a combination of two factors-ethnic heterogeneity of the population and the system of ethnic federalism. This may also help us resolve a seeming contradiction between predictions made by the contact and group threat theories.

According to the group threat literature, a large outgroup population is perceived by ethnic majorities as a threat; therefore, higher ethnic heterogeneity may lead to ethnic animosity and discrimination. This may well be the case in Moscow and St. Petersburg, where the level of ethnic discrimination is high. Both cities recently experienced mass migration from the Caucasus and Central Asia, and the ethnic heterogeneity there is largely the result of migration of ethnic groups that are often perceived as subordinate in status. In Kazan and Ufa, the share of non-ethnically Russian population is higher, but historically this is a result of Russian colonization rather than migration of non-Russian ethnic minorities. The population there has been split between ethnic Russians, Tatars, and Bashkirs for several centuries, without major changes happening in living memory. A long history of ethnic coexistence may reduce ethnic threat, both for ethnic Russians and the titular ethnic groups.

The contact theory predicts that more frequent contact between ethnic groups contributes to more positive inter-group relations, and therefore, ethnic mixing may reduce discrimination. What is often forgotten is that according to Allport (1954), inter-group conflict only ameliorates ethnic conflict under a number of conditions, including equal group status and support by authorities and institutions. In Moscow and St. Petersburg, recent immigrants are often occupationally segregated and work in low-skilled jobs in construction and services (Lokshin and Chernina, 2013). This reduces 
opportunities for contact with the locals, and when contact occurs it is often in social situations that imply unequal status. In Kazan and Ufa, Tatars and Bashkirs are titular ethnic groups whose special status in the republics is institutionally recognized. Ethnic Russians living in these regions do not have a primordial sense of territorial ownership structured along ethnic lines. Ethnic segregation in the labour market is low, and both ethnic Russians and Tatars are well represented in white-collar occupations, although the share of non-manual workers among ethnic Russians is somewhat larger (Giuliano, 2011). This may create more opportunities for everyday positive contacts between ethnic groups. Survey evidence suggests that the attitudes towards ethnic minorities of immigrant origin are more positive in Tatarstan and Bashkortostan compared with Moscow and St. Petersburg (Bessudnov, 2016).

Most students of ethnic federalism focused their attention on the effects of federalism on separatism (Erk and Anderson, 2009), whereas inter-ethnic attitudes in ethnic autonomous regions remain less widely studied (Alexseev, 2010; Minescu and Poppe, 2011). Our results are consistent with the findings from China, where Maurer-Fazio (2012) reported the absence of labour market discrimination against Mongolians in Inner Mongolia and against Uyghurs in Xinjiang (although these results pre-date the recent crackdown on Uyghur nationalism by the Chinese government). However, our argument is stronger, as it is not only titular ethnic groups who are not discriminated against in two of Russia's ethnic republics but also other non-indigenous groups of immigrant origin.

Given a small number of cases, we should be careful not to over-interpret these findings. Explanations of ethnic discrimination and conflict cannot be mechanically reduced to a few variables (Brubaker and Laitin, 1998). After all, a federal status and a long history of ethnic mixing did not prevent the ethnic massacre in Yugoslavia (Oberschall, 2000). Further studies of the effects, on discrimination, of ethnic autonomy and the ethnic composition of populations, may include a larger sample of Russia's regions; as well as cases from Western Europe (Northern Ireland, Scotland, Wales, Catalonia, the Basque country), China, India, and ethnic federations in Africa (such as Ethiopia and Nigeria).

\section{Notes}

1 In the experiment, we did not use the same names as in the survey, but they were selected using the same methodology.
2 The Bashkir population outside Bashkortostan is small, and Bashkir names are similar to Tatar ones. Initially, we included in the experiment a smaller number of Bashkir CVs, in Ufa only, but the sample size did not allow us to form any conclusions. We excluded Bashkir applications from all the reported analyses.

3 1C is a popular Russian software for accounting and enterprise management.

4 These results refer to hiring decisions only and can be different for gender inequalities in career development and wages.

\section{Supplementary Data}

Supplementary data are available at ESR online.

\section{Data Availability}

The data and replication materials for this article are available at https:/github.com/abessudnov/ruAuditPublic.

\section{Acknowledgements}

We are grateful to the research assistants who helped us with data collection: Alisa Alieva, Sergey Konontsev, Vladislav Kostin, Anastasia Roud, Pavel Savchenko, and Darya Smirnova. We also thank Jane Elliott; participants in the project 'Growth, Equal Opportunities, Migration and Markets'; and participants in seminars and conferences at the following venues, for their comments and questions: University of Oxford; University of Amsterdam; University of Exeter; King's College London; Laboratory for Comparative Social Research at the HSE in St. Petersburg; the HSE April 2018 conference; the Southern Sociological Association 2018 meeting; the American Sociological Association 2018 meeting; and the European Consortium for Sociological Research 2018 conference. The study has been approved by the ethics committees at the University of Exeter and the National Research University Higher School of Economics.

\section{Funding}

This study has been funded by the British Academy's International Partnership and Mobility grant (PM160023) and additionally supported by the Basic Research Programme at the National Research University Higher School of Economics (HSE) and the Russian Academic Excellence Project '5-100'.

\section{References}

Acolin, A., Bostic, R. and Painter, G. (2016). A field study of rental market discrimination across origins in France. Journal of Urban Economics, 95, 49-63. 
Agadjanian, V., Menjívar, C. and Zotova, N. (2017). Legality, racialization, and immigrants' experience of ethnoracial harassment in Russia. Social Problems, 64, 558-576.

Alba, R. (2005). Bright vs. blurred boundaries: second-generation assimilation and exclusion in France, Germany, and the United States. Ethnic and Racial Studies, 28, 20-49.

Alexseev, M. A. (2010). Majority and minority xenophobia in Russia: the importance of being titulars. Post-Soviet Affairs, 26, 89-120.

Allport, G. W. (1954). The Nature of Prejudice. Cambridge, MA: Addison-Wesley Publishing Company.

Arai, M., Bursell, M. and Nekby, L. (2016). The reverse gender gap in ethnic discrimination: employer stereotypes of men and women with Arabic names. International Migration Review, $50,385-412$.

Arnold, R. (2018). Russian Nationalism and Ethnic Violence: Symbolic Violence, Lynching, Pogrom and Massacre. London: Routledge.

Baert, S. (2018). Hiring discrimination: an overview of (almost) all correspondence experiments since 2005. In Michael Gaddis, S. (Ed.), Audit Studies: Behind the Scenes with Theory, Method, and Nuance. Cham, Switzerland: Springer, pp. 63-77.

Baert, S. et al. (2015). Is there less discrimination in occupations where recruitment is difficult? ILR Review, 68, 467-500.

Baert, S. et al. (2017). Does work experience mitigate discrimination? Economics Letters, 155, 35-38.

Bahry, D. (2016). Opposition to immigration, economic insecurity and individual values: evidence from Russia. Europe-Asia Studies, 68, 893-916.

Baldassarri, D. and Abascal, M. (2017). Field experiments across the social sciences. Annual Review of Sociology, 43, 41-73.

Baldini, M. and Federici, M. (2011). Ethnic discrimination in the Italian rental housing market. Journal of Housing Economics, 20, 1-14.

Bertrand, M. and Duflo, E. (2017). Field experiments on discrimination. In Banerjee, A. and Duflo, E. (Eds.), Handbook of Economic Field Experiments, Vol. 1. Amsterdam, Netherlands: North-Holland, pp. 309-393.

Bertrand, M. and Mullainathan, S. (2004). Are Emily and Greg more employable than Lakisha and Jamal? A field experiment on labor market discrimination. American Economic Review, 94, 991-1013.

Bessudnov, A. (2016). Ethnic hierarchy and public attitudes towards immigrants in Russia. European Sociological Review, 32, 567-580.

Blumer, H. (1958). Race prejudice as a sense of group position. Pacific Sociological Review, 1, 3-7.

Bobo, L. D. and Massagli, M. P. (2001). Stereotypes and urban inequality. In O'Connor, A., Tilly, C. and Bobo, L. D. (Eds.), Urban Inequality: Evidence from Four Cities. New York, NY: Russell Sage Foundation, pp. 89-162.

Bodrunova, S. S. et al. (2017). Who's bad? Attitudes toward resettlers from the post-Soviet south versus other nations in the Russian blogosphere. International Journal of Communication, 11, 3242-3264.

Booth, A. L., Leigh, A. and Varganova, E. (2012). Does ethnic discrimination vary across minority groups? Evidence from a field experiment. Oxford Bulletin of Economics and Statistics, 74, 547-573.

Browne, I. and Misra, J. (2003). The intersection of gender and race in the labor market. Annual Review of Sociology, 29, 487-513.

Brubaker, R. and Laitin, D. D. (1998). Ethnic and nationalist violence. Annual Review of Sociology, 24, 423-452.

Carlsson, M. and Eriksson, S. (2014). Discrimination in the rental market for apartments. Journal of Housing Economics, 23, 41-54.

Carlsson, M. and Eriksson, S. (2015). Ethnic discrimination in the London market for shared housing. Journal of Ethnic and Migration Studies, 41, 1276-1301.

Ceobanu, A. M. and Escandell, X. (2010). Comparative analyses of public attitudes toward immigrants and immigration using multinational survey data: a review of theories and research. Annual Review of Sociology, 36, 309-328.

Chapman, H. S. et al. (2018). Xenophobia on the rise? Temporal and regional trends in xenophobic attitudes in Russia. Comparative Politics, 50, 381-394.

Erk, J. and Anderson, L. (2009). The paradox of federalism: does self-rule accommodate or exacerbate ethnic divisions? Regional \& Federal Studies, 19, 191-202.

Ford, R. (2011). Acceptable and unacceptable immigrants: how opposition to immigration in britain is affected by migrants' region of origin. Journal of Ethnic and Migration Studies, 37, 1017-1037.

Foxall, A. (2014). Ethnic Relations in Post-Soviet Russia: Russians and Non-Russians in the North Caucasus. London: Routledge.

Gaddis, S. M. (2017). How Black are Lakisha and Jamal? Racial perceptions from names used in correspondence audit studies. Sociological Science, 4, 469-489.

Gerber, T. P. and Mayorova, O. (2010). Getting personal: networks and stratification in the Russian Labor Market, 1985-2001. American Journal of Sociology, 116, 855-908.

Giuliano, E. (2011). Constructing Grievance: Ethnic Nationalism in Russia's Republics. Ithaca, NY: Cornell University Press.

Gorenburg, D. (1999). Identity change in Bashkortostan: Tatars into Bashkirs and back. Ethnic and Racial Studies, 22, 554-580.

Gorenburg, D. (2003). Minority Ethnic Mobilization in the Russian Federation. Cambridge, UK; New York, NY: Cambridge University Press.

Gorodzeisky, A. (2019). Opposition to immigration in contemporary Russia. Post-Soviet Affairs, 35, 205-222.

Gorodzeisky, A. and Glikman, A. (2017). Two peoples-two stories: anti-immigrant attitudes in post-Socialist Russia. Social Problems, 65, 543-563.

Gorodzeisky, A., Glikman, A. and Maskileyson, D. (2015). The nature of anti-immigrant sentiment in post-socialist Russia. Post-Soviet Affairs, 31, 115-135. 
Green, D. P. and Vavreck, L. (2007). Analysis of cluster-randomized experiments: a comparison of alternative estimation approaches. Political Analysis, 16, 138-152.

Hagendoorn, L. (1995). Intergroup biases in multiple group systems: the perception of ethnic hierarchies. European Review of Social Psychology, 6, 199-228.

Hagendoorn, L., Poppe, E. and Minescu, A. (2008). Support for separatism in ethnic republics of the Russian Federation. Europe-Asia Studies, 60, 353-373.

Hagendoorn, L. et al. (1998). Inter-ethnic preferences and ethnic hierarchies in the former Soviet union. International Journal of Intercultural Relations, 22, 483-503.

Heath, A. and Cheung, S. Y. (Eds.) (2007). Unequal Chances: Ethnic Minorities in Western Labour Markets. Oxford: Oxford University Press.

Hirsch, F. (1997). The Soviet union as a work-in-progress: ethnographers and the category nationality in the 1926, 1937, and 1939 censuses. Slavic Review, 56, 251-278.

Hirsch, F. (2000). Toward an empire of nations: border-making and the formation of Soviet national identities. The Russian Review, 59, 201-226.

Hjerm, M. (2009). Anti-immigrant attitudes and cross-municipal variation in the proportion of immigrants. Acta Sociologica, 52, 47-62.

Kleg, M. and Yamamoto, K. (1998). As the world turns: ethno-racial distances after 70 years. The Social Science Journal, 35, 183-190.

Lancee, B. (2019). Ethnic discrimination in hiring: comparing groups across contexts. Results from a cross-national field experiment. Journal of Ethnic and Migration Studies (Published online 24 June 2019).

Lawson, J. (2015). Design and Analysis of Experiments with R. Boca Raton, FL: CRC Press.

Levada, C. (2016). "Otchyot Ob Issledovanii” Antisemitism v Sovremennoy Rossii. Technical report, available from: $<$ http://mcca.ru/uploads/default/files/\%D0\%BE\%D1\% $82 \%$ D1\%87\%D0\%B5\%D1\%82-\%D0\%9B\%D0\%B5\%D0\%B2 \%D0\%B0\%D0\%B4\%D0\%B0-\%D1\%80\%D1\%83\%D1\% 81.pdf $>$ [accessed 26 September 2019].

Levinson, A. (2016). "Evreyskiy Vopros" v Sovremennoy Rossii. Vestnik Obschestvennogo Mneniya, 1-2, 198-210.

Liebkind, K., Larja, L. and Brylka, A. A. (2016). Ethnic and gender discrimination in recruitment: experimental evidence from Finland. Journal of Social and Political Psychology, 4, 403-426.

Lokshin, M. and Chernina, E. (2013). Migrants on the Russian labor market: profile and earnings. HSE Economic Journal, 17, 41-74.

Markaki, Y. and Longhi, S. (2013). What determines attitudes to immigration in European countries? An analysis at the regional level. Migration Studies, 1, 311-337.

Martin, T. D. (2001). The Affirmative Action Empire: Nations and Nationalism in the Soviet Union, 1923-1939. Ithaca, NY: Cornell University Press.
Maurer-Fazio, M. (2012). Ethnic discrimination in China's internet job board labor market. IZA Journal of Migration, $1,12$.

Minescu, A., Hagendoorn, L. and Poppe, E. (2008). Types of identification and intergroup differentiation in the Russian. Journal of Social Issues, 64, 321-342.

Minescu, A. and Poppe, E. (2011). Intergroup conflict in Russia: testing the group position model. Social Psychology Quarterly, 74, 166-191.

Mironov, B. (2014). Rossiyskaya Imperiya: Ot Traditsii $k$ Modernu, Vol 1. St. Petersburg: Dmitry Bulanin.

Mironov, B. (2017). Ethnic discrimination in late imperial Russia. Vestnik of Saint Petersburg University: History, 62, 164-185.

Neumark, D. (2018). Experimental research on labor market discrimination. Journal of Economic Literature, 56, 799-866.

Oberschall, A. (2000). The manipulation of ethnicity: from ethnic cooperation to violence and war in Yugoslavia. Ethnic and Racial Studies, 23, 982-1001.

Osinsky, V. (1928). Mezhdunarodnye i Mezhkontinentalnye Migratsii $v$ Dovoennoy Rossii i SSSR. Moscow: Central Statistical Office.

Pager, D., Bonikowski, B. and Western, B. (2009). Discrimination in a low-wage labor market: a field experiment. American Sociological Review, 74, 777-799.

Perepis. (1928). Vsesoyouznaya Perepis Naseleniya 17 Dekabrya 1926 g.: Kratkie Svodki, Vol. 4. Moscow: Central Statistical Office.

Pettigrew, T. F. and Tropp, L. R. (2006). A meta-analytic test of intergroup contact theory. Journal of Personality and Social Psychology, 90, 751-783.

Pinkus, B. (1990). The Jews of the Soviet Union: The History of a National Minority. Cambridge: Cambridge University Press.

Public Opinion Foundation (2015). The Relationships between Russians and Ukrainians, available from: <https://fom.ru/ Mir/12099> [accessed 26 September 2019].

Quillian, L. (1995). Prejudice as a response to perceived group threat: population composition and anti-immigrant and racial prejudice in Europe. American Sociological Review, 60, 586-611.

Quillian, L. and Nanni, A. (2018). Is there a gender gap in discrimination in hiring? In American Sociological Association 2018 Meeting. https:/convention2.allacademic.com/one/ asa/asa18/index.php?program_focus=view_paper\&se lected_paper_id=1379869\&cmd=online_program_direct_ link\&sub_action=online_program [accessed 26 September 2019].

Riasanovsky, N. (2000). A History of Russia. New York, NY: Oxford University Press.

Rich, J. (2014). What Do Field Experiments of Discrimination in Markets Tell Us? A Meta Analysis of Studies Conducted Since 2000. IZA Discussion Paper No. 8584. Bonn: Institute for the Study of Labour. 
Romaniello, M. P. (2012). The Elusive Empire: Kazan and the Creation of Russia, 1552-1671. Madison, WI: University of Wisconsin Press.

Roshchin, S., Solntsev, S. and Vasilyev, D. (2017). Recruiting and job search technologies in the age of internet. Foresight and STI Governance, 11, 33-43.

Rosstat. (2012). Sotsialno-Demograficheskiy Portret Rossii Po Itogam Vserossiyskoy Perepisi Naseleniya 2010 Goda. Moscow: Statistika Rossii.

Rustenbach, E. (2010). Sources of negative attitudes toward immigrants in Europe: a multi-level analysis. International Migration Review, 44, 53-77.

Sakurai, K. and Okubo, Y. (2017). Job Seeker Trends 2017: Level of Satisfaction Gained by Changing Jobs. Tokyo: Boston Consulting Group.

Scherbakova, E. (2017). Migratsiya v Rossii, Predvaritelnye Itogi 2016 Goda. Demoscope Weekly, 719-720. http://www. demoscope.ru/weekly/2017/0719/barometer719.pdf [accessed 26 September 2019].

Semyonov, M., Raijman, R. and Gorodzeisky, A. (2006). The rise of anti-foreigner sentiment in European societies, 1988-2000. American Sociological Review, 71, 426-449.

Shcherbak, A. and Sych, K. (2017). Trends in Russian nationalities policy. Problems of Post-Communism, 64, 311-328.

Sidanius, J. and Pratto, F. (2001). Social Dominance: An Intergroup Theory of Social Hierarchy and Oppression. Cambridge: Cambridge University Press.

Sidanius, J. and Veniegas, R. (2000). Gender and race discrimination: the interactive nature of disadvantage. In Oskamp, S. (Ed.), Reducing Prejudice and Discrimination. Hoboken, NJ: Taylor and Francis, pp. 47-69.

Slezkine, Y. (1994). The USSR as a communal apartment, or how a socialist state promoted ethnic particularism. Slavic Review, 53, 414-452.

Tishkov, V. (1997). Ethnicity, Nationalism and Conflict in and after the Soviet Union: The Mind Aflame. London: Sage.
Verkuyten, M., Hagendoorn, L. and Masson, K. (1996). The ethnic hierarchy among majority and minority youth in the Netherlands. Journal of Applied Social Psychology, 26, 1104-1118.

Vernby, K. and Dancygier, R. (2019). Can immigrants counteract employer discrimination? A factorial field experiment reveals the immutability of ethnic hierarchies. PLoS One (Published online 24 July 2019).

Vujacic, V. (2007). Stalinism and Russian nationalism: a reconceptualization. Post-Soviet Affairs, 23, 156-183.

Yakubovich, V. (2005). Weak ties, information, and influence: how workers find jobs in a local Russian labor market. American Sociological Review, 70, 408-421.

Zick, A. et al. (2001). Acculturation and prejudice in Germany: majority and minority perspectives. Journal of Social Issues, 57, 541-557.

Zschirnt, E. and Ruedin, D. (2016). Ethnic discrimination in hiring decisions: a meta-analysis of correspondence tests 1990-2015. Journal of Ethnic and Migration Studies, 42, 1115-1134.

Alexey Bessudnov is a Senior Lecturer in quantitative sociology at the University of Exeter. His research interests are ethnic minorities and inequalities in education, in Russia and the UK. His work appeared in the European Sociological Review, the European Journal of Public Health, and other journals.

Andrey Shcherbak is a Deputy Head of the Laboratory for Comparative Social Research at National Research University Higher School of Economics, Russia. His research interests include ethnicity and nationalism, in particular, in the post-communist countries, and empirical studies of inter-ethnic relations in historical perspective. 